\title{
Why passengers' geo-demographic characteristics matter to airport marketing
}

\author{
Abraham Leung * \\ Barbara Yen * \\ Gui Lohmann *,\# \\ * Cities Research Centre, Griffith University, Brisbane, Australia \\ * Griffith Aviation, Griffith University, Brisbane, Australia
}

\begin{abstract}
Passengers' preference and origin location data (home postcodes) can be extremely useful for marketing purposes, with the potential for more effective customer segmentation and targeting, yet traditional airport market research has often neglected these aspects. This paper utilises passenger survey data from the Gold Coast Airport to perform a geo-demographic classification analysis in conjunction with census data. With geo-coded passenger preference data, the trip characteristics and airport decision preferences were cross-compared with demographic data with socio-economic variables. The results revealed distinctive contrasts in passenger origin location for short-haul domestic trips and long-haul international trips, in which passengers from afar are willing to travel longer distances to reach a second-tier airport to make use of cheaper airfares. One of the implications of this study is that low-cost carriers' businesses (the airlines or the airports) should better target their customers by offering geographically targeted marketing.
\end{abstract}

Keywords: low-cost carriers; airport marketing strategies; air passenger segmentation; Australia; geo-demographic analysis 


\section{Introduction}

In an age of increasing commercialisation and privatisation, the demand for air travel is growing rapidly, with airports facing increasing competition as the airline industry becomes more deregulated. Apart from investing in other aviation (e.g., ground handling companies) and nonaviation opportunities (all possible business activities in the airport precincts), airport operators are becoming more sophisticated in their marketing strategies in their attempts to attract passengers and generate revenue. Hence, it is of particular relevance to examine other marketing strategies airports can use; in this paper, we propose one model to incorporate geodemographic characteristics of passengers to improve airport marketing strategies.

This paper aims to implement geo-demographic segmentation within the aviation industry by using the Gold Coast Airport (OOL), Australia, and its catchment area in Southeast Queensland (SEQ) as a case study. In particular, we are interested in:

- proposing geo-demographic segmentation, by combining census and GIS datasets with data collected through a large passenger survey examining travel patterns and behaviour;

- determining specific target markets via spatial locations and market geo-demographic segmentation for the individual routes offered by the airport.

The outcomes of this study can provide airport managers and marketing decision makers with a better tool to examine the relationship between geo-demographic information and the travel preferences and choices of local outbound customers. This analysis can be coupled with an understanding of the essential criteria used, by clustering customers who choose a particular type of aviation service. This approach can allow airport marketing managers to develop more precise, targeted marketing strategies for different services to attract recurring and new customers. The proposed approach also advances the academic contribution to geodemographic application into different areas of the transport and tourism sectors (Bertazzon et al.,1997; Chancellor and Cole, 2008; Elliott-White and Finn, 1997; Miller, 2008). No previous academic study has applied geo-demographics in the case of airports, notably by examining outbound passengers. This fact is particularly relevant as airports are connecting terminals in between two different types of transport for outbound passengers; a ground transport trip to the airport and air travel to a faraway destination. In that regard, the travel patterns and behaviours of outbound air travel passengers are different from those of other modes of transport and focus on the 'origin' side of the trip, while most tourism studies concentrate on the 'destination' side.

The remaining parts of this paper are structured as follows. Section 2 provides a detailed literature review in the areas of travel and geo-demographics. Section 3 describes the study area and the research methodology used. Section 4 presents the results. The penultimate section discusses how geo-demographic data can be applied to airport marketing, including destination analysis. The last part concludes with avenues for further research and limitations. 


\section{Geo-demographics and its applicability in transport}

The previous research into demand modelling, or those developing choice models to forecast travel demand, is heavily focused on travel behaviour analysis (e.g., ground transport mode choice) or passengers' airline options. However, these studies have not considered or identified air passengers' geo-information, especially for geo-demographics. Without geo-referenced information, it is hard to relate passengers' choice behaviour within a market area, albeit this information is vital to better represent the airports' catchment areas. Of particular importance is to establish the market segmentation, market targeting and product/service positioning (Kaynak and Harcar, 2005). Currently, there are only a few studies into market segmentation and positioning in the field of consumer marketing (Hassan and Craft, 2005; Kaynak and Harcar, 2005; Kim and Ahn, 2008; Kuo et al., 2002). Micromarketing is an approach that has been widely used in four market levels: segments; niches; local areas; and individual customers (Kotler, 2003). Market size is decreasing from segments to individual levels. Peter and Donnelly (2004) pointed out that there is one general problem with the existing segmentation approaches: they fail to reveal geographic characteristics for identified groups and segments. For this reason, market segmentation should be coupled with geo-demographic information.

\section{Defining geo-demographics}

One of the most recognised definitions of geo-demographics is the profiling of people living in different areas, which links social and territorial data to produce segmented categories of space to identify the kinds of people who live in particular places' (Castree et al., 2013, no page). Alternatively, in simplifying terms, 'the analysis of people by where they live' (Sleight, 2004, pp. 16). Due to advances in computing power, allowing the combination of geographic information systems (GIS) and demographics, geo-demographics emerged as a tool for identification of the residential location of customers. This tool is particularly useful for marketers and decision makers to predict customers' preferences and responses (Goss, 1995). So far, it has led to early applications, notably in the field of marketing (Hassan and Craft, 2005; Mitchell, 1997; O'Malley et al., 1995; Rahbar and Abdul Wahid, 2011) and public health (Kimura et al., 2011; Nnoaham et al., 2010; Openshaw and Blake, 1995; Petersen et al., 2011; Tao et al., 2013). Yet, its application has been expanded to public order and safety (Ashby and Longley, 2005; Corcoran et al., 2013), education (Gibbs et al., 2010; Singleton, 2010), sociology (Mateos and Aguilar, 2013), tourism (as per previous references in the Introduction) and more recently to transport studies (Langford et al., 2012; McGill et al., 2012). Regarding airports in multiple airport regions (MAR), outbound passengers' bases (e.g., residential locations) become more and more necessary because of existing and increasing competition in MAR. Therefore, the geo-demographic technique can be a very powerful tool as it combines elements of geographic, demographic and personal preferences in an attempt to conduct a comprehensive analysis of customers' lifestyles. In other words, this geocode process allows passengers' residential locations - their target market - to be mapped.

There has been a significant increase in the use of geo-demographic segmentation methods in many disciplinary fields. These methods have developed into a thriving industry with a multitude of commercial segmentation systems constructed by a range of variables, including demographics, socio-economic levels, spending behaviour, and crime rates (Singleton and Spielman, 2014). Sophisticated commercial tools have been developed in the United Kingdom 
and are spreading to most industrialised countries with available and comprehensive census data (Leventhal, 2016; Sleight, 2004). The use of geo-demographics in marketing is widespread, but there is limited scholarly documentation due to the commercial confidentiality of its usage. For academic purposes, it is well implemented in public health - as mentioned above, with one of the challenges in undertaking research in this area being to survey demographic details of individual patients (Abbas et al., 2009). Its use in transport planning is also emerging, as geo-demographics is useful in identifying potential marketing areas to improve patronage and to tailor services, and the potential for developing sound business decisions for transport authorities (Páez et al., 2011). For airport studies, one of the few studies has been applied to Dallas/Fort Worth International Airport (Airport Cooperative Research Program, 2011), identifying passengers by different geo-demographic groups. This result was achieved by surveying passengers who used parking facilities. However, this study did not provide further analysis of the passengers' destinations, and the analysis was limited to passengers who drove to the airport. To identify the target market for outbound passengers, this study investigates passengers' travel behaviour by adopting the geo-demographic method. This approach has the potential to contribute to the multi-billion-dollar tourism marketing industry, as it focuses not only on the destination visited but also on a better understanding of outbound air travel from the 'origin' side of the trip.

\section{Transport and socio-demographic studies and applicability}

Schwanen and Mokhtarian (2005) suggested that passengers' travel distances can comprise two decisions, the decision to engage in travel and the conditional decision about the distance travelled, by considering a series of socio-demographic variables (e.g., income). Travel to airports by ground transport is unique in transport studies because air travel is relatively expensive compared to other modes of transport, although air travel has become nearly universally accessible in developed countries. In Australia, air transport dominates not just international travel, but also interstate displacements, mainly due to the limited transport options in the country's vast territory and relatively small population. Trips to airports are unique because of several reasons: 1) airports are usually located further away from residential areas due to environmental and safety requirements; 2) due to the 'mission critical' nature of the home-to-airport trip, passengers are willing to spend more money/time to make sure they arrive on time to catch the flight; 3) travel behaviour is more affected by socio-demographic characteristics. For example, the mode choice and airport choice from home to airports are influenced by different levels of income/location/time of the day, etc. Thus, socio-economic factors have a significant impact on travel patterns and distance of travel to the airport. Census based methods offer extensive information to a socio-demographic study to understand users' (passengers, in this study) characteristics. Census based research has been applied to many fields other than airport travel research, including commuting (Antipova et al., 2011; Manaugh et al., 2010), active travel (Parkin et al., 2007), and health-related travel such as trips to hospitals (Kim et al., 2013). However, studies regarding airport travel are relatively scant, in particular, travel from the home to the airport. As such, the other focus of this study is to consider the impacts of socio-economic factors to explain outbound passengers' travel patterns. These factors include a range of different socio-economic (e.g., income, occupation, education) and demographic (e.g., age, family composition, ethnicity) factors that passengers respond to sensitively during an airport survey. This study attempts to develop a geo-demographic methodology to study airport related travel in a growing MAR region of South East Queensland (SEQ), Australia. 


\section{Multiple airport regions (MARs)}

As part of the literature on MARs, Harvey (1987) undertook a seminal work studying the characteristics of airport choice for residents in the San Francisco Bay area. He identified that total travel time by ground transport to the airport and direct flights to the chosen destination were predominant factors for airport choice. Also studying the San Francisco Bay area, Pels et al. (2001) used discrete choice models to identify what variables are the most important determinants of passengers' choice of airports. Their results show that leisure passengers are more sensitive to airfare price (Lian and Rønnevik, 2011) while business travellers are more influenced by schedule convenience, are now common knowledge. Hence, price and schedule convenience are two key factors that need to be included in airport passenger surveys. More recent studies on airport and airline choice also identified a number of significant factors, such as the existence of airline lounges, preferred airline option, flight schedules, transport options to airport terminal, and airport retail options (Bezerra and Gomes, 2015; Cho et al., 2015; Jung and Yoo, 2014; Windle and Dresner, 1995). Lieshout (2012) points out the differences between leisure and business travellers in their choice of airports. Overall, business travellers are more sensitive to access time and frequency, with leisure passengers being less susceptible to time, willing to pay lower fares and travelling further to access departing airports (Lian and Rønnevik, 2011; Matisziw and Grubesic, 2010).

\section{Methodology}

\section{Gold Coast Airport (OOL) and its catchment area}

OOL is located in Coolangatta, which is the southernmost suburb of the Gold Coast in the state of Queensland and borders the state of New South Wales and Tweed Heads city. The airport serves some of the state capitals in Australia as well as regional towns in the country and a few destinations overseas. The airport building comprises a perk-free, single floor, common user terminal for domestic and international flights. Due to its lower operational costs (e.g., no airbridges connect the terminal to the planes), the airport has attracted low-cost carriers from Australia (e.g., Jetstar and Tiger) and overseas (e.g., Scoot, AirAsia and Jetstar). In late 2013 and early 2014, when the data were collected for this research, OOL had 5,767,478 passengers, $85 \%$ of whom were domestic passengers, making OOL the sixth busiest airport in Australia. Domestic routes were operated by all the major domestic airlines, i.e., Virgin Australia, Qantas, Jetstar and Tiger Airways. Virgin Australia, which operated on a 'hybrid' business model (Lohmann and Koo, 2013), flew to most of the state capital cities and territories, except Darwin. Qantas, the major national legacy full-service network carrier, only served Sydney, and Tiger Airways flew to Sydney and Melbourne. International routes from OOL included Kuala Lumpur (operated by AirAsia), Singapore (Scoot), Auckland (Virgin Australia and Air New Zealand), and Osaka and Tokyo (Jetstar). With the exception of the Auckland route, the other three international routes were not operated by the respective airlines at Brisbane Airport (BNE), which is OOL's closest competitor. In many ways, this difference gave OOL a small competitive advantage over BNE, particularly in the low-cost segment.

The SEQ region is comprised of three rapidly growing areas, Brisbane, the Gold Coast and the Sunshine Coast, which have merged into a 200-kilometre linear city (Spearritt, 2009). However, Brisbane and the Gold Coast are the two predominant economic and population powerhouses, 
with two major international airports, located 90 kilometres apart. This study involves the postcodes surrounding OOL catchment area in SEQ and Northern New South Wales, as shown in Figure 1. The road distance of the postcodes to OOL are estimated by Google Maps from the centroid of each postcode. While a geopolitical separation exists between the cities of Gold Coast and Tweed Heads, the latter gravitates around the Gold Coast, which is one of the largest and fastest growing cities in Australia (Dredge and Jamal, 2013). The socio-economic agglomeration between the Gold Coast and Tweed Heads is evident in local planning governance, as Tweed Heads is recognised in the Regional Planning in SEQ (Queensland Government, 2009). North of the Gold Coast, two urban regions comprise the catchment area of the airport; the Logan and Brisbane regions, in addition to postcodes from the Redland City Council (e.g., Cleveland and North Stradbroke Island) and parts of the hinterland, such as Tamborine Mountain. Logan comprises a transitional region between the Gold Coast and the urban areas of Brisbane, the state capital city where BNE is located. Postcodes within the Logan City Council area are characterised by high industrial and commercial activities and a population with a younger but also lower socio-economic background (higher unemployment rates) in comparison with Brisbane and the SEQ region. The area south of the Gold Coast consists of a set of sprawling rural communities and towns whose primary economic focus is on tourism and agriculture (Bock and Brunckhorst, no date). The Northern Rivers region was designated as including passengers living in the northeast corner of the state of New South Wales, more precisely, including Byron Bay, Ballina, Lismore, Kyogle and Casino.

[Insert Figure 1 about here]

\section{Data collection}

The data used in this study are based on three primary sources - survey, census and geographical data. The survey developed for this research includes some questions associated with the principal aspects of passengers' travel patterns and behaviours in travelling to and while at the airport, as well as the reasons for their choice of a particular airport. To achieve the research goals, a set of questions was developed to capture information on passengers' travel patterns and their selection of OOL, including home postcodes, reasons for flying out of OOL, the size of travel groups and the modes of transport used to arrive at the airport. The second set of questions focused on the behaviour of passengers while at the airport. Finally, the last set of questions addressed information about the trip from the airport, including the flight number (time and destination), visits to other destinations in Australia or overseas and the number of nights spent away on the trip. The survey was then uploaded to the iSurvey app and, through the use of iPads, a team of five researchers was used to survey random passengers at the airport terminal who were waiting to board a plane. A sample of 4,681 passengers beginning their trips at the terminal (outbound market) was collected between October 2013 and January 2014, with surveys been undertaken during 76 different days, covering the airport operation from 6 am to $11 \mathrm{pm}$. Passengers were screened out based on the postcodes of their place of residence, with only those living within the stipulated catchment area being invited to complete the survey. While the questionnaire was designed for passengers travelling both domestically and internationally, the survey was only carried out in English because it was intended for local residents. Only passengers over the age of 18 were approached, and when there was a group travelling together, only one person from the group was invited to participate in the survey. 
Survey data provide individual/passenger level data of trip-related information. However, due to the short timeframe of survey questioning, it is not possible to probe the detailed backgrounds of the respondents. As the postcodes of the respondents were obtained, it was then feasible to link the survey data with other geographically based data, such as census data (Table 1). The latest census of 2011, conducted by the Australian Bureau of Statistics, is used. As there are a large number of census variables that might be related to passenger travel patterns, such as age, socio-economic, ethnicity and movement data, a geo-demographic approach is used to reduce the complexity and summarise the data into geo-demographic groups. While it is feasible to use over-the-shelf geo-demographic classifications such as the Experian MOSIAC ${ }^{\mathrm{TM}}$, it was found that these classifications are nationally based, and do not have the ability show the subtle nuances at regional (SEQ) level. Therefore, in this study, a bespoke geo-demographic classification was created by clustering the geo-demographic variables within the region. Another advantage of using the clustering tool developed by the researchers in this study is the lower costs incurred. Examples of bespoke geo-demographic classification have been attempted in the transport (Bearman and Singleton, 2015) and the education fields in the UK.

[Insert Table 1 about here]

\section{Geo-demographic classification process}

Geo-demographic classifications are summarised groups of populations that are geographically and demographically similar. There are several advantages associated with this method, including the potential marketing strategies used by airport authorities to influence travel patterns and behaviours by postcode, or the possibility of cross-linking census statistics by postcode, employing the sample/clusters developed in this research. Commonly, it is achieved by multivariate statistical methods, ranging from k-mean clustering, principal component analysis (PCA) or hierarchical agglomerative clustering (Leventhal, 2016). In this study, these methods were tested to explore which could provide the best fit for classification. K-means clustering was found to be the most suitable for the trial and error method. K-means clustering is used to partition large amounts of data into sensible groupings. This method originated in signal processing and then expanded to other applications such as statistics, machine learning in computer sciences, and market segmentation analysis (Kuo et al., 2002; Jain, 2010). An example of k-mean clustering for geo-demographic data is the Area Classification for Output Areas (United Kingdom Office for National Statistics, 2015) and it is also the backbone of classification methods used in other commercial geo-demographic classifications. Before applying k-means clustering, the input data were normalised and standardised by transforming each variable into z-scores, with the variables converted into an index with the mean value becoming zero. This step is essential to allow meaningful comparison of postcodes within the study region for a further clustering process by the k-mean method in the SPSS 22 software. Twelve geo-demographic cluster groups of the postcodes were formed after processing the variables with k-mean clustering. These are detailed in Appendix 1 and are mapped in Figure 2. The resulting groups summarised the overall socio-economic status (weekly income and level of home ownership) and also show some degree of urbanisation level (population density and degree of urbanised areas). The resident population size is plotted in Figure 3 to provide a simplified summary of the groups in relation to generalised socio-economic status and urbanisation level. The geo-demographic clustering is then evaluated by comparison with the trip related data obtained from the survey. 
[Insert Figure 2 about here]

[Insert Figure 3 about here]

\section{Results}

The classification of the geo-demographic characteristics of the postcode can be used to compare the survey results. Figures 4 and 5 show the share of these classifications of trips departing $\mathrm{OOL}$ on domestic and international flights, respectively.

[Insert Figure 4 about here]

[Insert Figure 5 about here]

Various thresholds are found in the literature in determining an airport's catchment area. Examples included 50 kilometres radius distance (Ringbeck, 2007), 75 miles (approximately 120 kilometres) radius distance (Fuellhart, 2007), 80\% nearest market share area of passengers (United Kingdom Civil Aviation Authority, 2011), and isochrones of one- and twohour land travel (Augustyniak and Olipra, 2014). As there is no consensus in the literature, and based on data available in SEQ, we adopted a threshold of 50 kilometres land travel distance (approximately one-hour travel) of postcode centroids to distinguish local and long-distance airport users. Using this threshold, distinctive patterns of geo-demographic classifications and trip preferences can be observed. The 50-kilometre distance from the OOL (blue areas in Figure 1 ) is roughly the area where the 'local catchment area' of the OOL is, where passengers can reach the OOL in less than one hour by car. What has been possible to affirm is that there is a higher proportion of passengers who travel to international destinations which originate from outside the local 50-kilometre catchment area (42\%) when compared with domestic destinations (24\%). There is also a higher tendency for passengers travelling from outside the Gold Coast to catch international flights.

As shown in Figure 5, for the geo-demographic groups residing within the local catchment area surveyed, 'Seachange Retirees' constitutes the largest group of domestic and also international passengers. However, the distribution for international passengers outside the Gold Coast is more diverse, including the 'Multicultural Urbanites', 'Rural Living' and 'Aspiring Families', 'Comfortable Families' and 'Seachange Retirees'. 'Multicultural Urbanites' is one of the higher income groups, this could imply they have greater spending ability for long-haul and more expensive trips. A similar comparison can also be done with the flight distance of the trip. Figure 6 shows the average flight distances of the geo-demographic groups. The dotted line denotes the mean value of the geographic groups of both the local catchment area and the area outside it. Geo-demographic groups outside the local catchment area tend to travel longer distances, in particular, 'Comfortable Families', 'Multicultural Urbanites', 'Students around Campus' and 'Little Asia', which are well over the average flight distance. Taking 'Students around Campus' as an example, this group has a higher proportion of international students who tend to be more likely to fly internationally.

[Insert Figure 6 about here] 
In addition to simplistic analysis of survey results, geo-demographic studies usually adopt an indexation approach. The $\mathrm{EV}_{\mathrm{g}}$, which refers to the expected value of the number of trips at group level, which is calculated with consideration of the survey response (e.g., trips) and the underlying population of the postcode.

$$
E V_{g}=\frac{\sum \text { trips }}{\sum \text { pop }} \times \sum \text { pop }_{g}
$$

$\mathrm{IV}_{\mathrm{g}}$ is the sum of trips per group, which can then be normalised into a mean adjusted index as indexed value (IV), where 100 denotes the mean value.

$$
I V_{g}=\frac{\sum \text { trips }}{E V_{g}} \times 100
$$

For this case, the distance is separated into two groups (within and beyond $50 \mathrm{~km}$ from the $\mathrm{OOL}$ ). While it is possible to analyse the data by creating more distance groups, the survey count in this study is not large enough to avoid the issue of statistical outliers for a more refined analysis. The confidence intervals are also calculated to provide a measure of sensitivity, which is based on Byar's approximation, as outlined in other geo-demographic studies (Corcoran et al., 2013; Singleton and Longley, 2008)

$$
\begin{aligned}
& I V_{\text {Lower }}=I V_{g}\left(1-\frac{1}{9 O}-\frac{Z_{\propto / 2}}{3 \sqrt{O}}\right)^{3} \\
& I V_{\text {Upper }}=I V_{g}\left(\frac{O+1}{O}\right)\left(1-\frac{1}{9(O+1)}-\frac{Z_{\propto / 2}}{3 \sqrt{O+1}}\right)^{3}
\end{aligned}
$$

Where $O$ is the observed number of trips for a particular geo-demographic group. $Z_{\alpha / 2}$ is the value of the standard normal distribution for the given significance level, which is 95\% confidence in this case with an alpha of 0.005 and $Z_{\alpha / 2}$ of 1.96 . Figure 7 shows the index score of domestic and international trips. 'Seachange Retirees' and 'Brisbane CBD' are significantly higher than mean value in both trip types. However, 'Students around Campus' are considerably higher in the case of international travel.

[Insert Figure 7 about here]

The survey questions on the reason to choose OOL can provide some explanation of such differences in the air travel pattern. As is generally thought, "Students around Campus" are indeed more attracted by affordable fares as they are more likely to indicate such as a reason to choose OOL, more so than other groups (Figure 8). In contrast, the 'Seachange Retirees', 'Brisbane CBD' and 'Rural Living' geo-demographic groups are also attracted by easy access. It 
could also be reasonably inferred that the 'Brisbane CBD' is located in a more convenient area with higher availability of transport options to the OOL, such as highway access, shuttle bus services, and the AirTrain rail services. For the 'Seachange Retirees' and 'Rural Living' populations, they are probably less time constrained and find access to OOL is not a significant issue, albeit only BNE is linked by the rail service, with trains stopping 15 kilometres from OOL (bus routes connect the train station to $\mathrm{OOL}$ ). Plans are currently in place to link $\mathrm{OOL}$ via the Gold Coast tram line. For the 'Aspiring Families' groups, it is likely they are located in postcodes that have good highway access to the OOL. However, other groups are less likely to provide such a response.

\section{[Insert Figure 8 about here]}

Index score analysis can also be done by comparing the types of trips (Personal vs Business). Figure 9 shows that personal journeys (including leisure or visiting friends and relatives) are more likely to be undertaken by the 'Students around Campus' groups. It is probable these trips are more price sensitive and hence related to the pattern of the affordable fare, as shown in Figure 8. Additional analysis is done to compare the type of carrier (low-cost carrier vs. fullservice carrier) as shown in Figure 10, which shows similar patterns to Figure 9.

[Insert Figure 9 about here]

[Insert Figure 10 about here]

In general, higher income geodemographic groups travel further in distance, more likely to travel international flights and fly with full-service carriers. Conversely, lower income geodemographic groups are more likely to choose OOL for affordable fares, which are characterised by domestic flights and fly with low-cost carriers. Certain groups exhibit special behaviours, such as student around campus are more likely to travel international flights but with a strong preference for affordable fares provided by low-cost carriers.

\section{A discussion on why postcodes matter for airport marketing}

The survey could also be analysed at postcode level, which can provide in-depth information and a geographic distribution of the patterns of preferences of air travel in SEQ. However, caution should be exercised when analysing specific destinations geographically at a postcode level, as some postcodes had a low number of responses, which can lead to the problem of small area sampling bias. This can be addressed by viewing the data with population adjusted values. The destination counts of each postcode are aggregated and adjusted by population to show the rate of trips of the postcode. Figure 11 shows the destination groups of domestic flights (within Australia) and international flights to New Zealand (Christchurch and Auckland), South East Asia (SEA, including Singapore, and Kuala Lumpur) and Japan (Tokyo and Osaka).

[Insert Figure 11 about here]

The interplay of access time, price and airport competition could offer an explanation of the differences of travel characterise showcased above. While for this research we were not able to collect data from Brisbane International Airport, we can infer that the difference of travel distance is quite universal and apply to most markets. That is, passengers are more likely to 
travel longer in-flight distances if they require longer on-ground distance to the airport. The figures in this paper show that domestic flight passengers are highly concentrated in areas closer to the OOL, as shown in Figure 4.

While it could be possible to give examples using each destination served from the OOL, international trips warrant more attention due to higher profit potential as international passengers tend to spend more than domestic ones (Laesser and Crouch, 2006). By looking at specific international destinations (New Zealand, South-East Asia (SEA) and Japan), while the patterning of higher concentration of passenger nearer OOL, the incidence of trips is more scattered across geography and appears to be related to the distance of travel and, to some extent, related to geodemographic characteristics. For example, New Zealand trips are only about three hours from the OOL, and the areas with higher trip rates are more likely to be located closer to the OOL.

It should be noted that all the long haul flights at OOL are all operated by low-cost carriers. In Figure 10, it shows that longer haul flights are more likely to attract customers from Brisbane. Using an example of SEA trips, by overlying the geo-demographic classification map with one of the destination groups, in this case, SEA trips as shown in Figure 11, the areas which attracted more trip rates can be easily compared. For this destination group, the Kuala Lumpur flight is operated by AirAsia and the Singapore flight is operated by Scoot. Looking at the geodemographic patterns, a higher proportion of people who are en route to or from Singapore reside in the 'Multicultural Urbanites' postcode area, but such people are less likely to be found in the 'Aspiring Families' postcodes. There are also other hotspots in the southern suburbs of Brisbane, notably the 'Students around Campus'. The price might have an effect on airport choice. Using Singapore as an example, for the return trip airfare between BNE/OOL to Singapore (prices taken from the airline websites and skyscanner.com), the lowest price of a Scoot flight from OOL is AU\$358 (return trip). Whereas the cheapest direct flight options on the same date from BNE by the flagship carrier Emirates/Qantas code shared flight is AU\$782 (return trip), and Singapore Airlines is AU\$821 (return trip).

The findings presented in Figures 8 and 11 imply that passengers are willing to forgo at least two hours of travel time for cheaper flights ( $\sim 50 \%$ cheaper in this case) from the OOL. Similar analysis can be applied to other destinations if needed. However, it would be beyond the scope of this paper to investigate the in-depth underlying factors for the subtle nuances of different patterning of trip incidence across geographic space, nor does the survey offer us enough explanation. Nevertheless, this shows that geo-demographic analysis can help develop market analysis at postcode level. Integration of geo-demographic clusters with airport passenger surveys offers more information for airport and airlines operators in many ways, especially in marketing analysis. Firstly, postcode specific marketing based on geodemographic classifications can be conducted based on the survey data. Airline advertisement can be focused in the areas with a tendency to travel to specific destinations. For example, billboards can be placed in the areas with higher tendency to travel to Singapore as identified in Figure 12. This strategy would be more effective than blanket marketing in the whole SEQ area. The geodemographic marketing strategy proposed is also applicable to other routes, airlines and even airports. Secondly, the demographic data can be used to predict from which areas people are more likely to travel to a particular destination. This approach can improve planning efforts for airlines and airports. Airlines and airports can predict the size of the potential market and 
develop appropriate plans or strategy to expand routes in the future based on geo-demographic analysis.

[insert Figure 12 about here]

\section{Concluding notes and future research directions}

This study is pioneering the application of geo-demographic methods in airport studies. We are not aware of any other published study that has used similar methods. This method links socioeconomic variables taken from census data to an airport passenger survey by cross-linking geodemographic classifications of postcodes. This method provides useful insights for airport managers and airline operators in better understanding postcode information related to air transport passengers. It also allows a multitude of analyses to demonstrate how the airport, in this study the OOL, attracts customers positioning itself as an alternative for low-cost carriers, offering affordable fares to long-haul destinations. There is much scope for future work to analyse survey data in conjunction with geo-demographic methods showcased in this paper. For instance, detailed regression analysis of passengers' travel choices and demographic backgrounds by modelling the correlations of travel behaviour and demographic characteristics can be performed at postcode level. For future surveys, this study highlighted the importance of 'geo-coding' data to allow a geographic perspective to be implemented. In fact, several studies (Elwood, Goodchild, \& Sui, 2012; Graham \& Shelton, 2013) have noted the possibility of 'big data' being incorporated into geo-demographic analysis or volunteered geographic information in the form or smartphone apps and loyalty programmes. The current trend to utilise 'big data' is clearly promising as, in the case of aviation, it is possible to cross-relate data with the enormous data sets of airline passenger data held by airlines. This trend, however, can lead to privacy concerns which need to be addressed to allow the ethical use of big data (Webber, Butler, \& Phillips, 2015).

It should be noted that there are several limitations to this study which need to be addressed in future investigations. Firstly, the census data were from 2011, but the survey was conducted in late 2013 to early 2014. While this gap does not affect the findings significantly, however, new urban developments could have occurred during this two-year gap which might have resulted in certain areas that are not synchronised with the survey results. This issue is also identified in the geo-demographic literature (Leventhal, 2016) as many marketing applications require yearly or even quarterly updates of background data, which a five-yearly census could render outdated in such applications. Nevertheless, this issue can be properly addressed as more airport operators are willing to conduct ongoing research with their passengers to understand trends and patterns over time. This approach will provide useful information about various marketing possibilities, including for example, understanding how changes in flights and destinations impact on passenger travel patterns by individual postcodes and their shopping behaviour at airports. This method will lead to airport marketing strategies that are much more sophisticated than at the present time. Another limitation of this study is the size of the postcode areas in Australia, as they are rather coarse-grained, compared to other jurisdictions such as the UK (where a postcode encompasses only 15 households). This matter is probably the reason why the UK has for decades been a fertile ground for geo-demographic research. The official statistical agencies in Australia also do not provide granular level geo-demographic 
classification such as the Output Areas Classification (OAC) in the UK (United Kingdom Office for National Statistics, 2015), which could help researchers or data users to devise better marketing strategies. Nevertheless, it appears that even at postcode level, an airport passenger survey coupled with the geo-demographic classification of census data could be highly useful in informing marketing strategies in the current climate of an increase in competition between airports within multiple airport regions. Also, future studies looking at MAR should consider multiple airports, not just one of the airports. Yet in this paper we are able to infer some of the role of competition in airport passenger travel patterns.

This paper is highly relevant to the increasingly competitive airport scene. Further research in this field could improve decision making at all levels: 1) airport managers to identify potential areas for more targeted marketing efforts; 2) airline operators can better target their customers, and as identified in this paper, a large proportion of long-haul passengers are coming beyond the local catchment area of the Gold Coast. This highlights the need to provide convenient transport connection services for these customers, such as door-to-door shuttles or parking incentives; 3) transport authorities can plan for airport infrastructure and transport connections to airports; 4) tourism agencies in other regions can examine how tourists are travelling prior to arriving at their destinations. In fact, the third abovementioned point has been underresearched. In a more globalised world, future research into tourism needs to look at 'outbound' flows, not just 'in-bound' flows.

This paper has provided a comprehensive analysis based on geo-demographic methods. In the future, more research of this kind could enrich the field of airport studies and provide crosscomparison opportunities for this growing field.

\section{References}

Abbas, J., Ojo, A., \& Orange, S. (2009). Geo-demographics - a tool for health intelligence? Public Health, 123, e35-e39. doi:10.1016/j.puhe.2008.10.007

Airport Cooperative Research Program (2011). Resource Manual for Airport In-terminal Concessions, ACRP report. Washington, D.C.: Transportation Research Board.

Antipova, A., Wang, F., \& Wilmot, C. (2011). Urban land uses, socio-demographic attributes and commuting: A multilevel modeling approach. Applied Geography, 31, 1010-1018. doi:10.1016/j.apgeog.2011.02.001

Ashby, D. I., \& Longley, P. A. (2005). Geocomputation, geo-demographics and resource allocation for local policing. Transactions in GIS, 9, 53-72. doi:10.1111/j.14679671.2005.00205.x

Augustyniak, W., Olipra, Ł., 2014. The potential catchment area of Polish regional airports. Journal of International Studies, 7, 144-154. doi:10.14254/2071-8330.2014/7-3/13

Bearman, N., \& Singleton, A. D. (2015). TravelOAC: Development of travel geo-demographic classifications for England and Wales based on open data. Presented at the GIS Research UK (GISRUK) 2015 Conference, Leeds. UK.

Bertazzon, S., Crouch, G., Draper, D., \& Waters, N. (1997). GIS applications in tourism marketing: Current uses, an experimental application and future prospects. Journal of Travel \& Tourism Marketing, 6, 35-59. doi:10.1300/J073v06n03_04

Bezerra, G. C. L., \& Gomes, C. F. (2015). The effects of service quality dimensions and passenger characteristics on passenger's overall satisfaction with an airport. Journal of Air Transport Management, 44-45, 77-81. doi:10.1016/j.jairtraman.2015.03.001

Castree, N., Kitchin, R., \& Rogers, A. (2013). A Dictionary of Human Geography, Oxford Paperback Reference. Oxford University Press, Oxford. 
Chancellor, C., \& Cole, S. (2008). Using Geographic Information Systems to visualize travel patterns and market research data. Journal of Travel \& Tourism Marketing, 25, 341-354. doi:10.1080/10548400802508440

Cho, W., Windle, R. J., \& Dresner, M. E. (2015). The impact of low-cost carriers on airport choice in the US: A case study of the Washington-Baltimore region. Transportation Research Part E: Logistics and Transportation Review, 81, 141-157. doi:10.1016/j.tre.2015.06.004

Corcoran, J., Higgs, G., \& Anderson, T. (2013). Examining the use of a geo-demographic classification in an exploratory analysis of variations in fire incidence in South Wales, UK. Fire Safety Journal, 62-A, 37-48. doi:10.1016/j.firesaf.2013.03.004

Dredge, D., \& Jamal, T. (2013). Mobilities on the Gold Coast, Australia: Implications for destination governance and sustainable tourism. Journal of Sustainable Tourism, 21, 557-579. doi:10.1080/09669582.2013.776064

Elliott-White, M. P., \& Finn, M. (1997). Growing in sophistication: The application of Geographical Information Systems in post-modern tourism marketing. Journal of Travel \& Tourism Marketing, 7, 65-84. doi:10.1300/J073v07n01_05

Elwood, S., Goodchild, M. F., \& Sui, D. Z. (2012). Researching volunteered geographic information: Spatial data, geographic research, and new social practice. Annals of the Association of American Geographers, 102, 571-590. doi:10.1080/00045608.2011.595657

Fuellhart, K., 2007. Airport catchment and leakage in a multi-airport region: The case of Harrisburg International. Journal of Transport Geography, 15, 231-244. doi:10.1016/j.jtrangeo.2006.08.001

Gibbs, A., Stillwell, J., \& See, L. (2010). A geo-demographic classification of London primary schools. In Proceedings of the GIS Research UK. 18th Annual Conference GISRUK 2010. Presented at the GIS Research UK 18th Annual Conference, pp. 17-27.

Goss, J. (1995). "We know who you are and we know where you live": The instrumental rationality of geodemographic systems. Economic Geography, 71, 171-198. doi:10.2307/144357

Graham, M., \& Shelton, T. (2013). Geography and the future of big data, big data and the future of geography. Dialogues in Human Geography, 3, 255-261. doi:10.1177/2043820613513121

Harvey, G. (1987). Airport choice in a multiple airport region. Transportation Research Part A: General, 21, 439-449. doi:10.1016/0191-2607(87)90033-1

Hassan, S. S., \& Craft, S. H. (2005). Linking global market segmentation decisions with strategic positioning options. Journal of Consumer Marketing, 22, 81-89. doi:10.1108/07363760510589244

Jung, S.-Y., \& Yoo, K.-E. (2014). Passenger airline choice behavior for domestic short-haul travel in South Korea. Journal of Air Transport Management, 38, 43-47. doi:10.1016/j.jairtraman.2013.12.017

Kaynak, E., \& Harcar, T. D. (2005). American consumers' attitudes towards commercial banks: A comparison of local and national bank customers by use of geo-demographic segmentation. International Journal of Bank Marketing, 23, 73-89. doi:10.1108/02652320510577375

Kim, K., \& Ahn, H. (2008). A recommender system using GA K-means clustering in an online shopping market. Expert Systems with Applications, 34, 1200-1209. doi:10.1016/j.eswa.2006.12.025

Kim, S., Chukwudozie, B., \& Calhoun, E. (2013). Socio-demographic characteristics, distance to the clinic, and breast cancer screening results. Journal of Health Disparities Research and Practice, 6, 70-88.

Kimura, Y., Saito, R., Tsujimoto, Y., Ono, Y., Nakaya, T., Shobugawa, Y., Sasaki, A., Oguma, T., \& Suzuki, H. (2011). Geo-demographics profiling of influenza A and B virus infections in community neighborhoods in Japan. BMC Infectious Diseases, 11, 36-47. doi:10.1186/1471-2334-11-36

Kotler, P. (2003). Marketing Management, 11th ed. Upper Saddle River, N.J.: Prentice Hall. 
Kuo, R. J., Ho, L. M., \& Hu, C. M. (2002). Integration of self-organizing feature map and Kmeans algorithm for market segmentation. Computers \& Operations Research, 29, 1475-1493. doi:10.1016/S0305-0548(01)00043-0

Langford, M., Higgs, G., \& Fry, R. (2012). Using floating catchment analysis (FCA) techniques to examine intra-urban variations in accessibility to public transport opportunities: The example of Cardiff, Wales. Journal of Transport Geography, 25, 1-14. doi:10.1016/j.jtrangeo.2012.06.014

Laesser, C., \& Crouch, G. I. (2006). Segmenting markets by travel expenditure patterns: The case of international visitors to Australia. Journal of Travel Research, 44, 397-406.

Leventhal, B. (2016). Geo-demographics for marketers: Using location analysis for research and marketing, Marketing Science series. Kogan Page, London \& Philadelphia.

Lian, J. I., \& Rønnevik, J. (2011). Airport competition - Regional airports losing ground to main airports. Journal of Transport Geography, 19, 85-92. doi:10.1016/j.jtrangeo.2009.12.004

Lieshout, R. (2012). Measuring the size of an airport's catchment area. Journal of Transport Geography, 25, 27-34. doi:10.1016/j.jtrangeo.2012.07.004

Lohmann, G., \& Koo, T. T. R. (2013). The airline business model spectrum. Journal of Air Transport Management, 31, 7-9. doi:10.1016/j.jairtraman.2012.10.005

Manaugh, K., Miranda-Moreno, L. F., \& El-Geneidy, A. M. (2010). The effect of neighbourhood characteristics, accessibility, home-work location, and demographics on commuting distances. Transportation, 37, 627-646. doi:10.1007/s11116-010-9275-z

Mateos, P., \& Aguilar, A. G. (2013). Socio-economic segregation in Latin American cities. A geo-demographic application in Mexico City. Journal of Settlements \& Spatial Planning, 4, 11-25.

Matisziw, T. C., \& Grubesic, T. H. (2010). Evaluating locational accessibility to the US air transportation system. Transportation Research Part A: Policy and Practice, 44, 710722. doi:10.1016/j.tra.2010.07.004

McGill J., Church, N., Gleeson, D., Rogers, A., \& Doonan, K. (2012). Not everyone gets a backpack; developing a targeted approach to travel behavior change. In: Australasian Transport Research Forum 2012.

Miller, F. L. (2008). Using a GIS in Market Analysis for a Tourism-Dependent Retailer in the Pocono Mountains. Journal of Travel \& Tourism Marketing, 25(3-4), 325-340. doi:10.1080/10548400802508416

Mitchell, S. (1997). Parallel universes: Experian sorts the global population into geodemographic clusters. Marketing Tools, 4, 14-17.

Nnoaham, K. E., Frater, A., Roderick, P., Moon, G., \& Halloran, S. (2010). Do geo-demographic typologies explain variations in uptake in colorectal cancer screening? An assessment using routine screening data in the south of England. Journal of Public Health, 32, 572 581. doi:10.1093/pubmed/fdq025

O'Malley, L., Patterson, M., \& Evans, M. (1995). Retailing applications of geo-demographics: A preliminary investigation. Marketing Intelligence \& Planning, 13, 29-35. doi:10.1108/02634509510083482

Openshaw, S., \& Blake, M. (1995). Geo-demographic segmentation systems for screening health data. Journal of Epidemiology \& Community Health, 49, S34-S38.

Páez, A., Trépanier, M., \& Morency, C. (2011). Geo-demographic analysis and the identification of potential business partnerships enabled by transit smart cards. Transportation Research Part A: Policy and Practice, 45, 640-652. doi:10.1016/j.tra.2011.04.002

Parkin, J., Wardman, M., Page, M. (2007). Estimation of the determinants of bicycle mode share for the journey to work using census data. Transportation, 35, 93-109. doi:10.1007/s11116-007-9137-5

Pels, E., Nijkamp, P., \& Rietveld, P. (2001). Airport and airline choice in a multiple airport region: An empirical analysis for the San Francisco Bay Area. Regional Studies, 35, 1-9. doi:10.1080/00343400120025637

Peter, J. P., \& Donnelly, J. H. (2004). Marketing Management: Knowledge and skills, 7th ed. Boston, MA: McGraw-Hill. 
Petersen, J., Gibin, M., Longley, P., Mateos, P., Atkinson, P., \& Ashby, D. (2011). Geodemographics as a tool for targeting neighbourhoods in public health campaigns. Journal of Geographical Systems, 13, 173-192. doi:10.1007/s10109-010-0113-9

Queensland Government (2009). South East Queensland Regional Plan 2009. Brisbane, QLD: Queensland Government.

Rahbar, E., \& Abdul Wahid, N. (2011). Investigation of green marketing tools' effect on consumers' purchase behavior. Business Strategy Series, 12, 73-83. doi:10.1108/17515631111114877

Ringbeck, J., 2007. Effectively planning and managing European airport capacity, in: Conrady, R., Buck, M. (Eds.), Trends and Issues in Global Tourism 2007. Springer Berlin Heidelberg, Berlin, Heidelberg, pp. 69-79.

Schwanen, T., \& Mokhtarian, P. L. (2005). What if you live in the wrong neighborhood? The impact of residential neighborhood type dissonance on distance traveled. Transportation Research Part D: Transport and Environment, 10, 127-151. doi:10.1016/j.trd.2004.11.002

Singleton, A. D. (2010). The geo-demographics of educational progression and their implications for widening participation in higher education. Environment and Planning $A$, 42, 2560-2580. doi:10.1068/a42394

Singleton, A. D., \& Longley, P.A. (2008). Creating Open Source Geo-demographic Classifications for Higher Education Applications. Working Paper. CASA, UCL.

Singleton, A. D., \& Spielman, S.E. (2014). The past, present, and future of geo-demographic Research in the United States and the United Kingdom. The Professional Geographer, 66, 558-567. doi:10.1080/00330124.2013.848764

Sleight, P. (2004). Targeting Customers: How to use geo-demographic and lifestyle data in your business. Henley-on-Thames: World Advertising Research Center.

Spearritt, P. (2009). The 200 km city: Brisbane, the Gold Coast, and Sunshine Coast. Australian Economic History Review, 49, 87-106. doi:10.1111/j.1467-8446.2009.00251.x

Tao, L., Liu, J., \& Xiao, B. (2013). Effects of geo-demographic profiles on healthcare service utilization: a case study on cardiac care in Ontario, Canada. BMC Health Services Research, 13, 239-248. doi:10.1186/1472-6963-13-239

United Kingdom Civil Aviation Authority, 2011. Catchment area analysis, Working Paper. United Kingdom Civil Aviation Authority, London.

United Kingdom Office for National Statistics (2015). Methodology Note for the 2011 Area Classification for Output Areas. London, England.

Webber, R. J., Butler, T., \& Phillips, T. (2015). Adoption of geodemographic and ethno-cultural taxonomies for analysing Big Data. Big Data \& Society, 2, 1-16. doi:10.1177/2053951715583914

Windle, R., \& Dresner, M. (1995). Airport choice in multiple-airport regions. Journal of Transportation Engineering, 121, 332-337. doi:10.1061/(ASCE)0733947X(1995)121:4(332) 


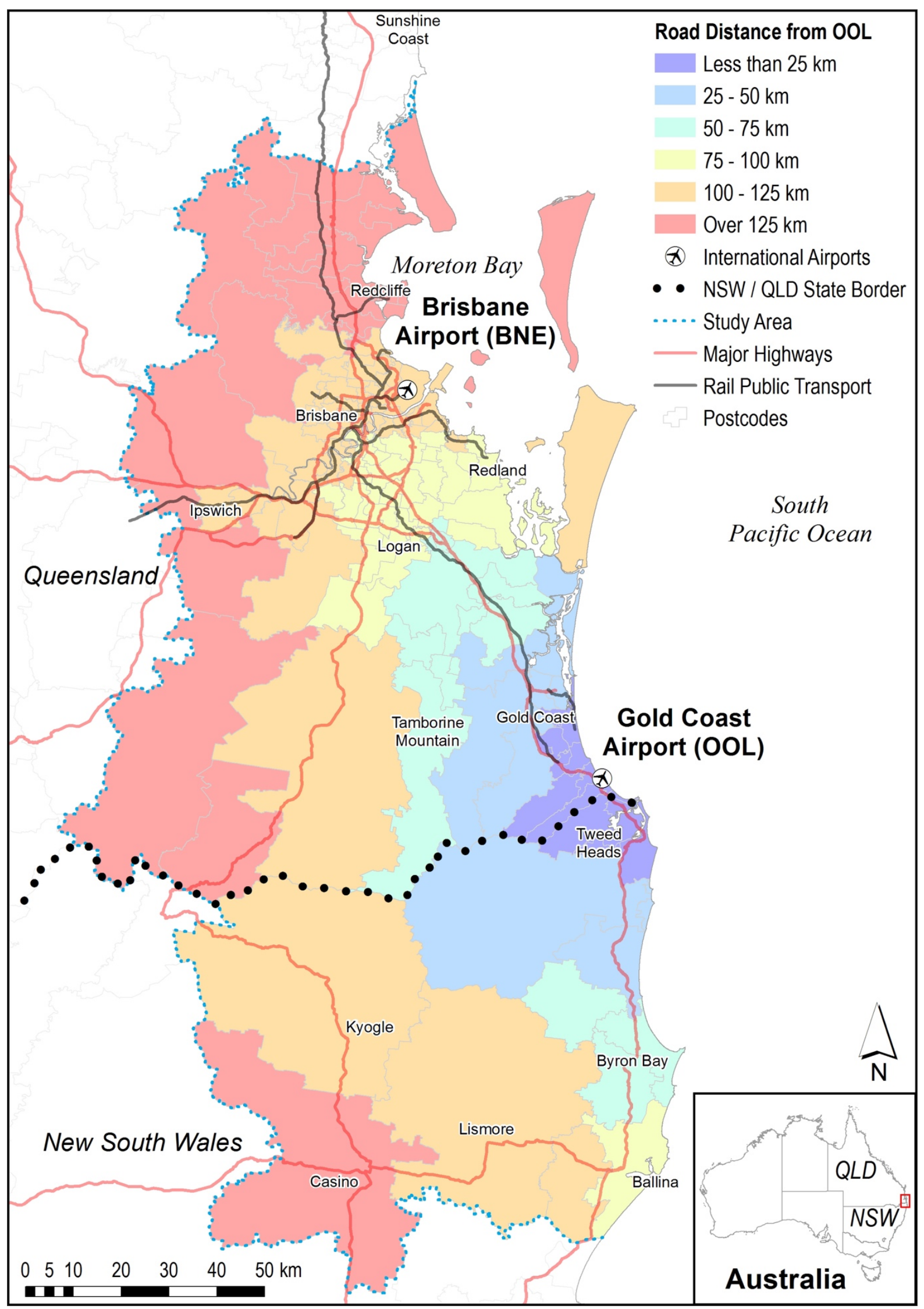

Figure 1: Gold Coast Airport catchment area (blue postcodes are classified as 'local catchment area') 
Table 1: Variables used in the study

\begin{tabular}{|c|c|}
\hline Source & Selected / Example of variables used in this study \\
\hline \multirow{7}{*}{$\begin{array}{l}\text { Trip-related data } \\
\text { (passenger survey) }\end{array}$} & Flight destination (main and flight destinations) and distance \\
\hline & Distance from home postcode to airport \\
\hline & Preference of flights (reason for choosing OOL) \\
\hline & Trip purpose \\
\hline & Trip duration \\
\hline & Group size (not used) \\
\hline & Mode to airport (not used) \\
\hline \multirow{7}{*}{$\begin{array}{l}\text { Geo-demographic data } \\
\text { (based on Australian } \\
\text { Bureau of } \\
\text { Statistics(ABS) Census } \\
\text { data processed in GIS) }\end{array}$} & Age groups \\
\hline & $\begin{array}{l}\text { Household characteristics } \\
\text { - } \text { Marriage status } \\
\text { - } \text { Family composition (number of dependent children) } \\
\text { - } \text { School status (kindergarten, primary, secondary, tertiary) } \\
\end{array}$ \\
\hline & $\begin{array}{l}\text { Dwelling characteristics } \\
\text { - Type of dwellings (house, flat, etc.) } \\
\text { - Tenure (owned, mortgage, rent, public housing) } \\
\text { - High rent/mortgage payment }\end{array}$ \\
\hline & $\begin{array}{cl}\text { Socio-economic status } \\
\text { - Weekly family income } \\
\text { - Highest education attained } \\
\text { - Unemployment rate } \\
\text { - Occupation (professionals, sales, blue collar workers, etc.) }\end{array}$ \\
\hline & $\begin{array}{l}\text { Ethnicity } \\
\text { - Self-identified ancestry } \\
\text { - Language spoken at home } \\
\text { - Citizenship }\end{array}$ \\
\hline & $\begin{array}{l}\text { Transport } \\
\text { - Primary mode to work (car or public transport) } \\
\text { - Vehicle ownership }\end{array}$ \\
\hline & $\begin{array}{l}\text { Urban Form } \\
\text { • } \quad \text { Land use } \\
\text { • }\end{array}$ \\
\hline
\end{tabular}




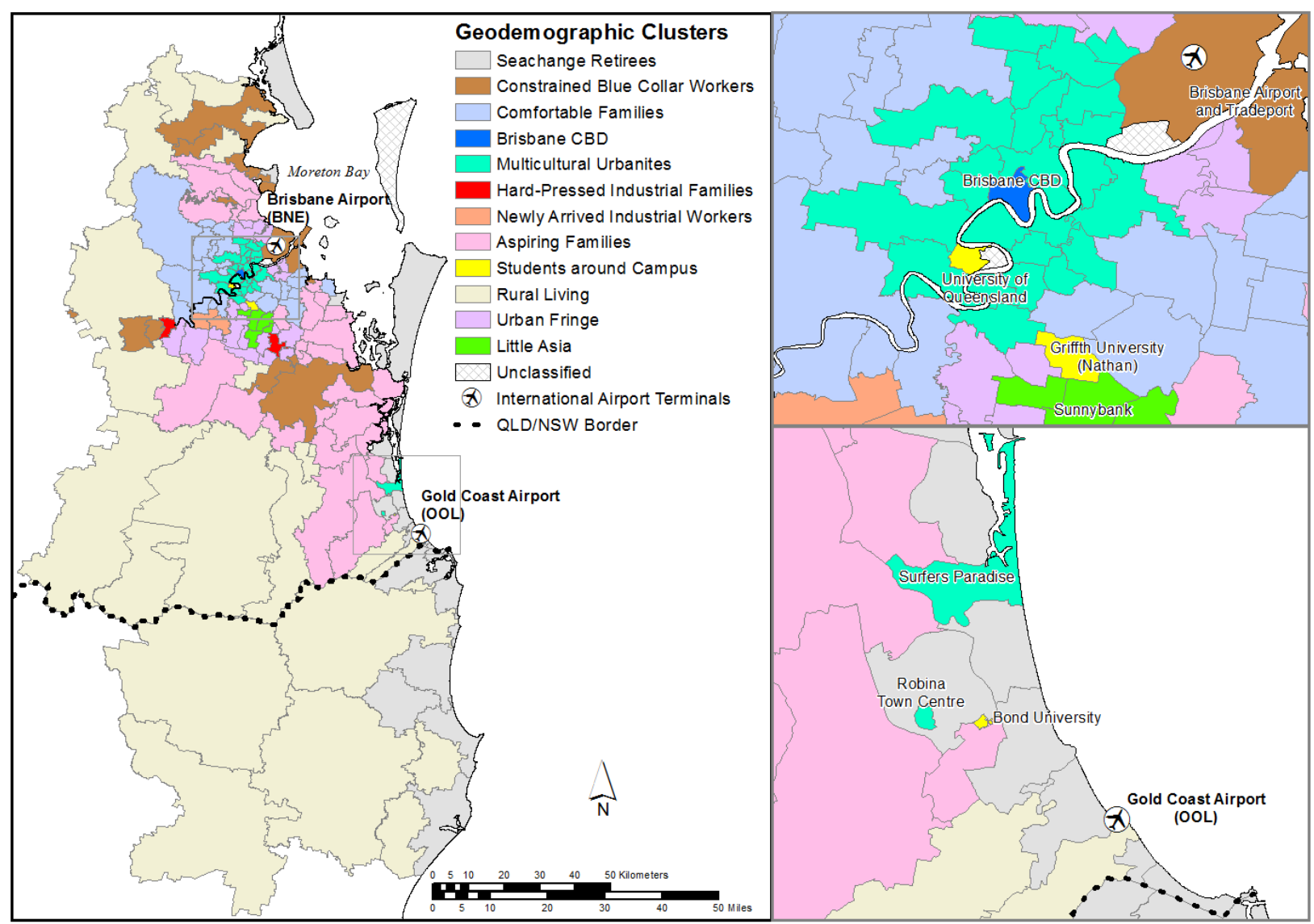

Figure 2: Distribution of geo-demographic groups (postcodes) across the study region 


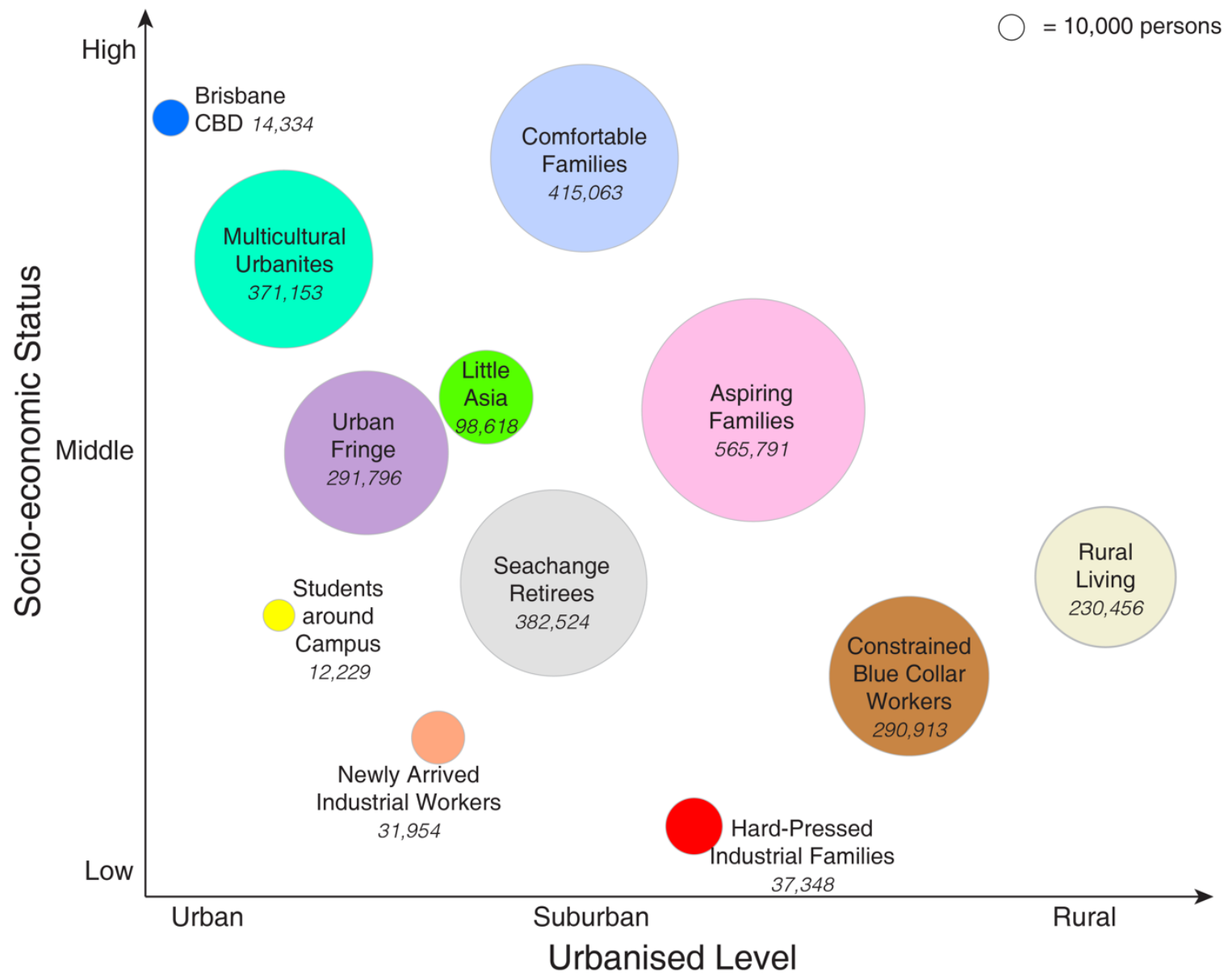

Figure 3: Socio-economic status and urbanised level by geo-demographic groups (size of circle denote population share of the group) 


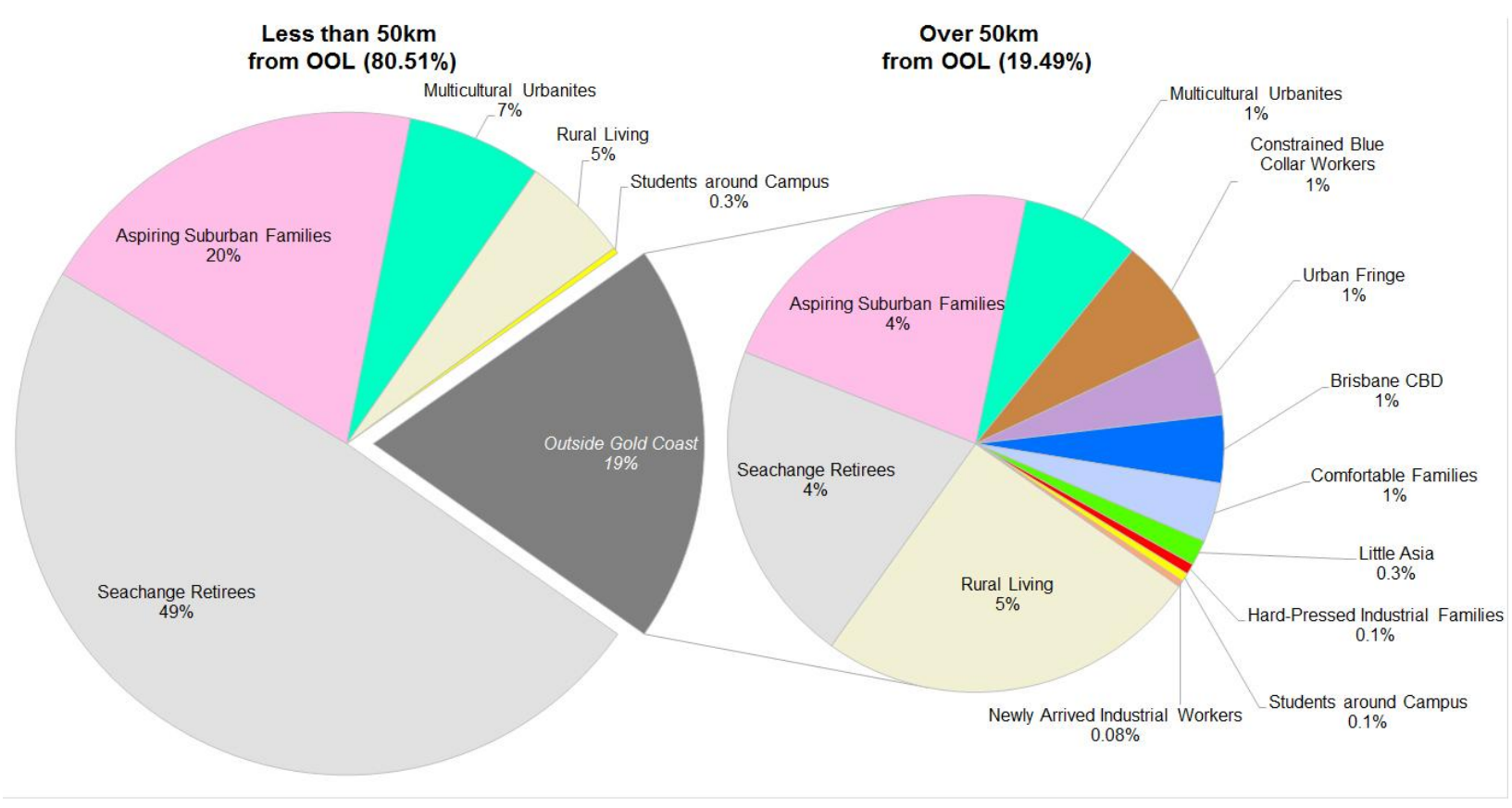

Figure 4: Local passengers travelling to domestic destinations $(n=3,715)$ 


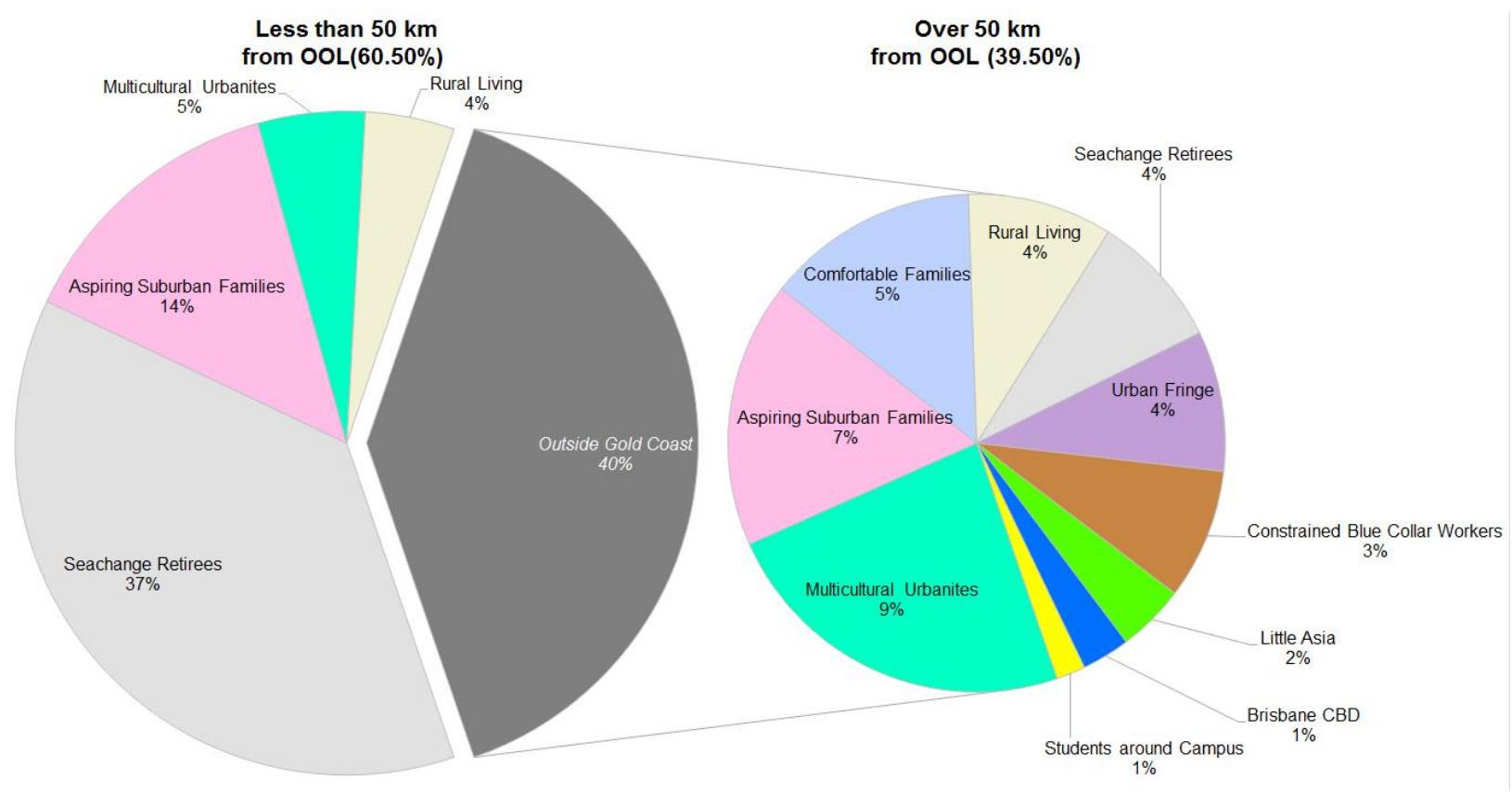

Figure 5: Local passengers travelling to international destinations $(n=805)$ 


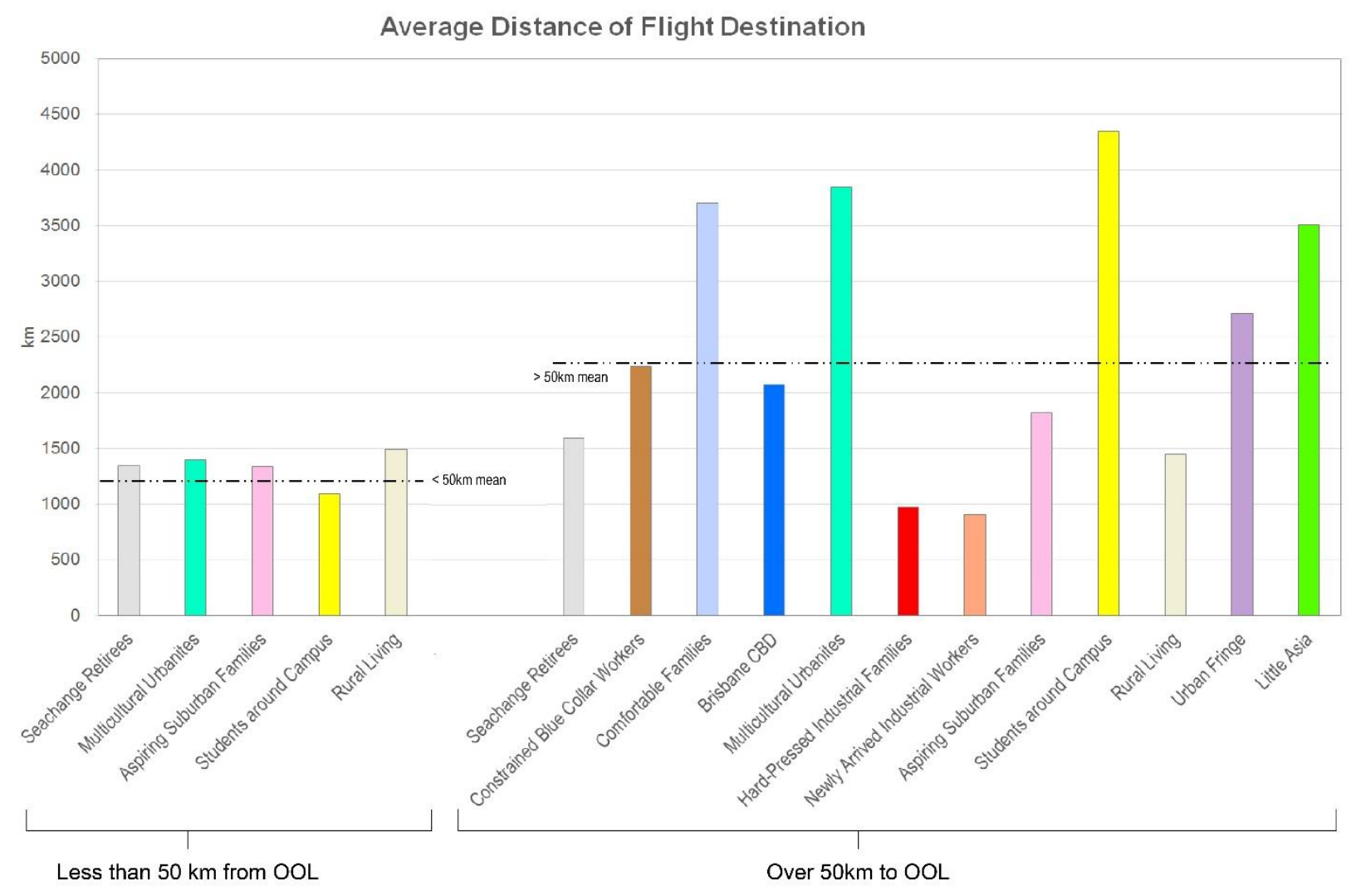

Figure 6: Mean flight distance of passengers by geo-demographic groups (dotted line denotes the mean values within and outside $50 \mathrm{~km}$ postcodes of the $\mathrm{OOL}$ ) 

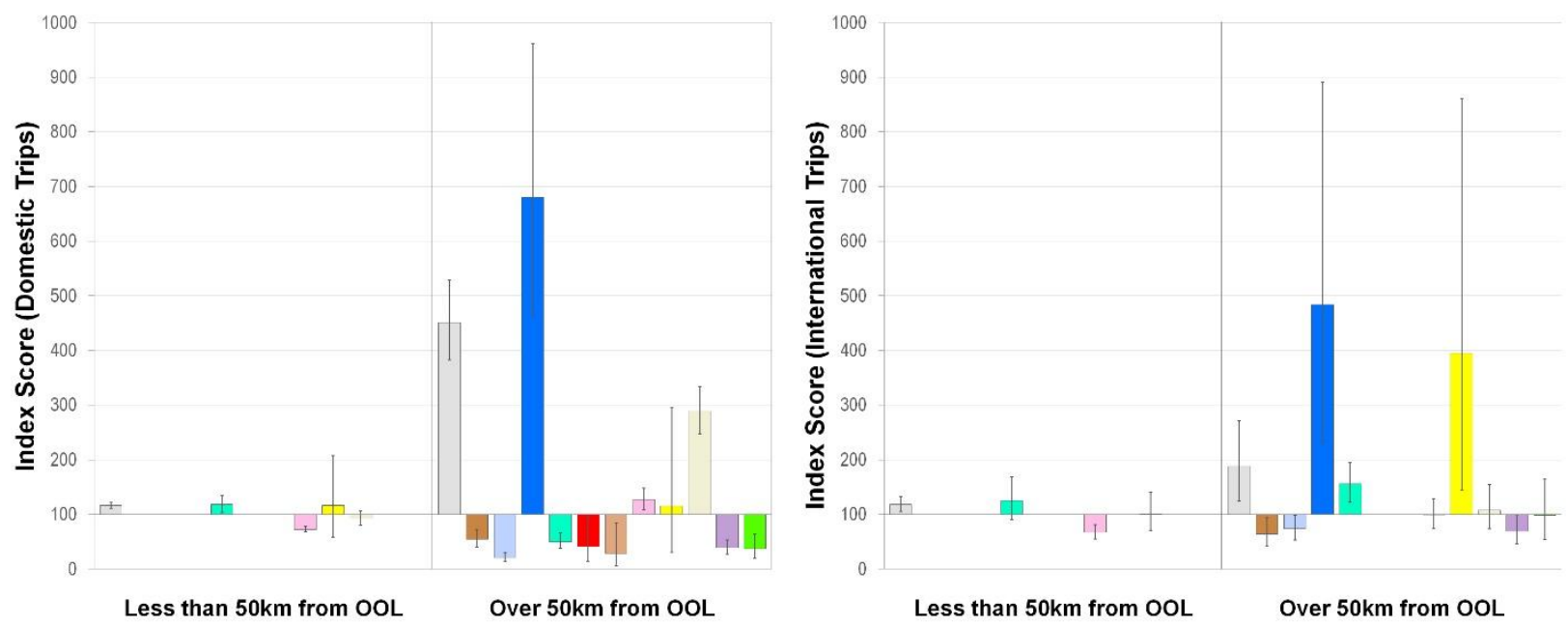

Figure 7: Index scores for domestic and international passenger ground travel by geodemographic groups 


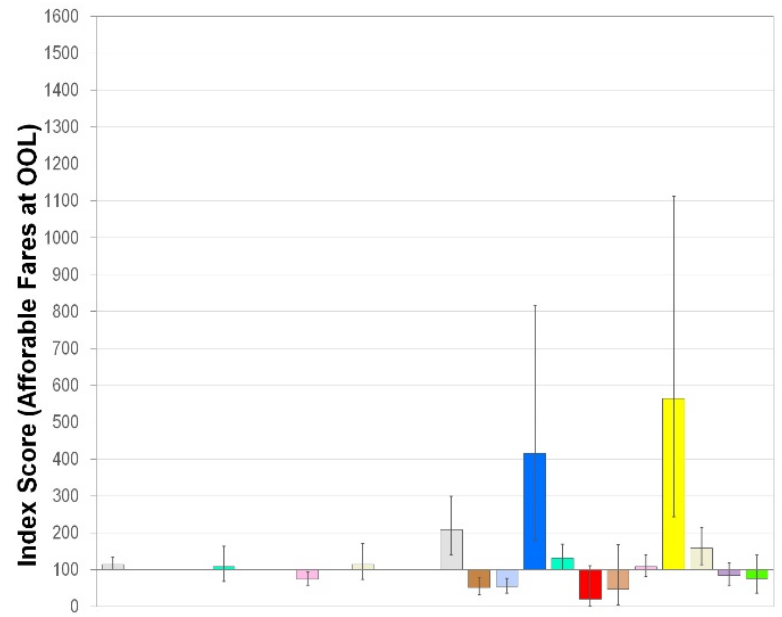

Less than $50 \mathrm{~km}$ from $\mathrm{OOL}$

- Seachange Retirement

- Brisbane CBD

- Migrant Industry SE Asian Workers

Rural Life

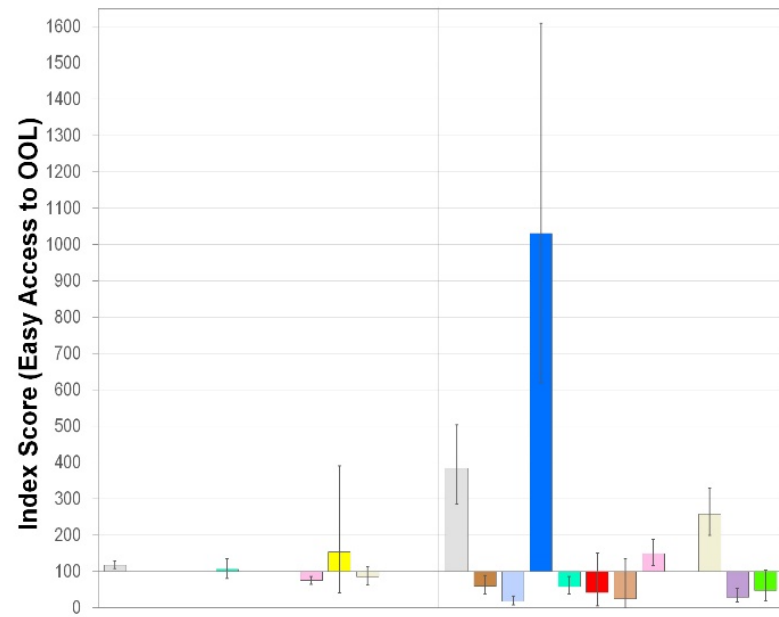

Less than $50 \mathrm{~km}$ from $\mathrm{OOL}$

Over $50 \mathrm{~km}$ from oOL

$\square$ Comfortable Families

- Hard-Pressed Ethnic Industrial Families

ᄀ Students around Campus

aulticultural Urbanites

$\square$ Aspiring Suburban Families

- Urban Fringe Ethnic Families

$\square$ Little Asia

Figure 8: Index score for the main reasons of choosing OOL 


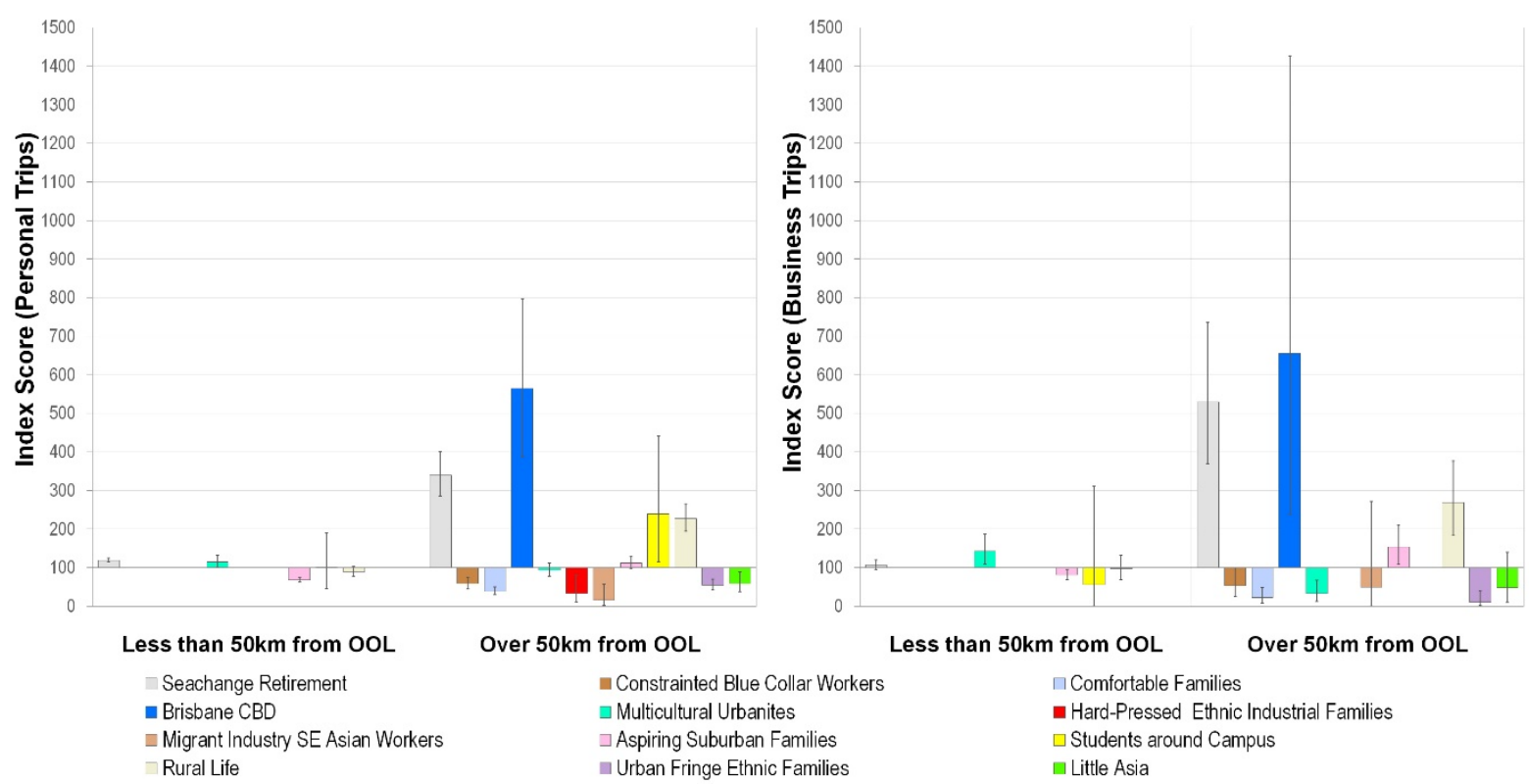

Figure 9: Index score of the types of trip (personal and business) 

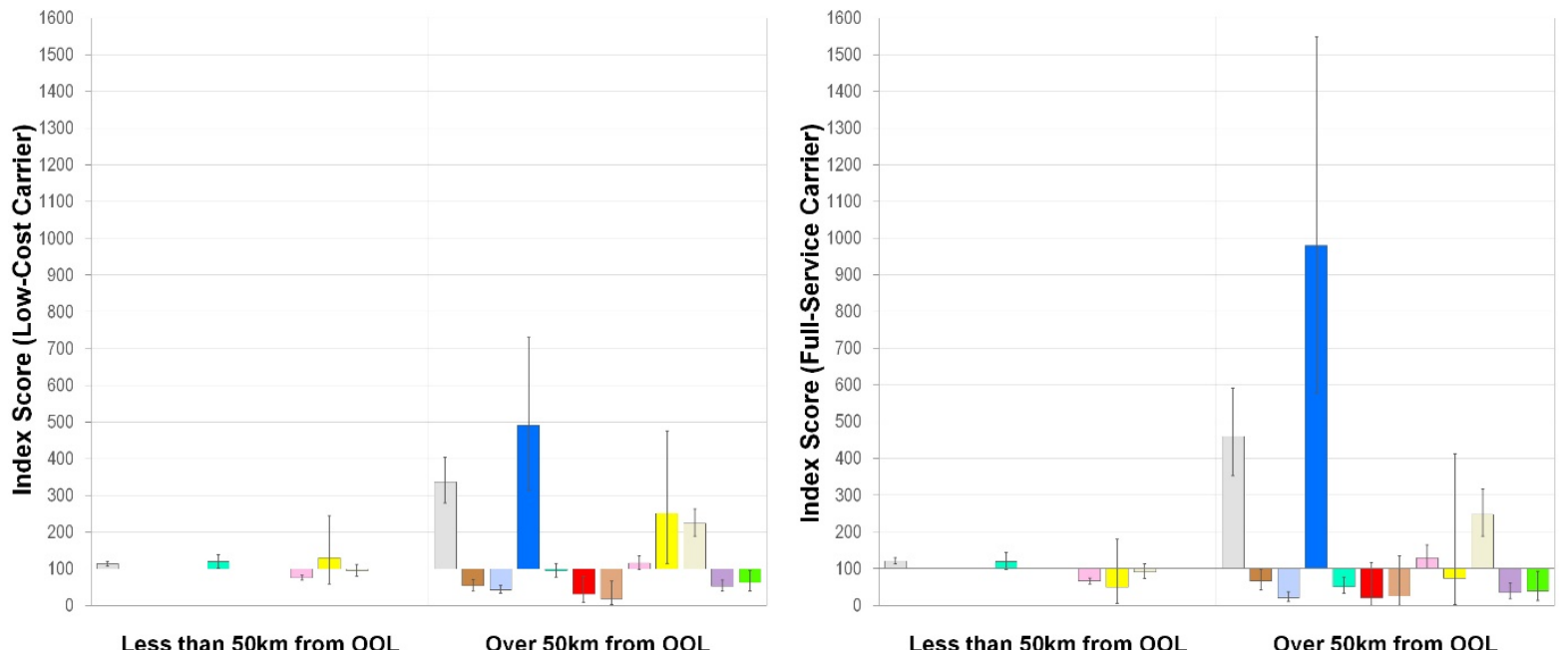

$\begin{array}{ll}\square \text { Seachange Retirement } & \square \text { Constrainted Blue Collar Workers } \\ \square \text { Brisbane CBD } & \square \text { Multicultural Urbanites } \\ \square \text { Migrant Industry SE Asian Workers } & \square \text { Aspiring Suburban Families } \\ \text { Rural Life } & \square \text { Urban Fringe Ethnic Families }\end{array}$

Less than $50 \mathrm{~km}$ from $\mathrm{OOL}$

Over $50 \mathrm{~km}$ from $\mathrm{OOL}$

$\square$ Comfortable Families

- Hard-Pressed Ethnic Industrial Families

$\square$ Students around Campus

- Little Asia

Figure 10: Index score of the types of airlines (full-service and low-cost carriers) 


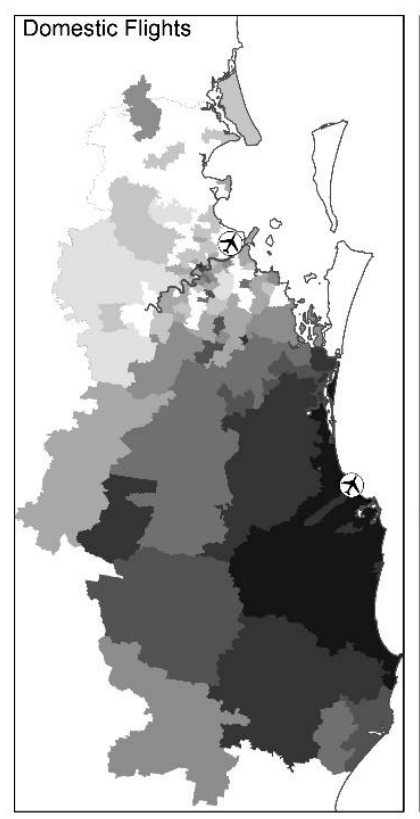

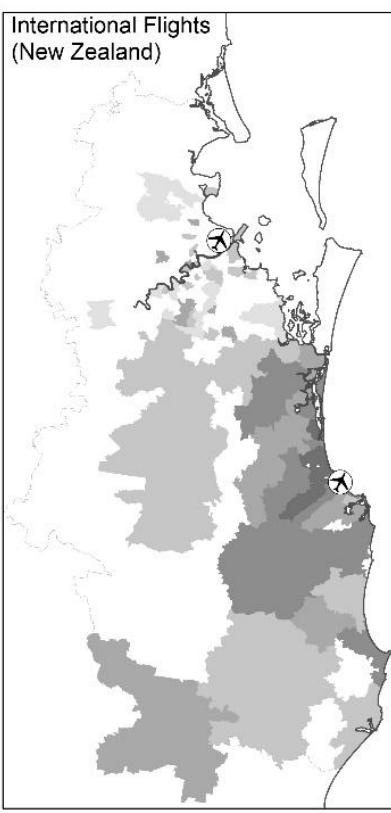

Rate of Trips (per 1,000 population) $\begin{array}{llllllllll}0 & 0.01 & 0.05 & 0.125 & 0.25 & 0.5 & 1 & 2 & 5 & 10 \text { and over }\end{array}$
International Flights

(SEA - Singapore \& Kuala Lumpur)

(5)

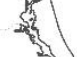

$\sqrt{2}$

ax?

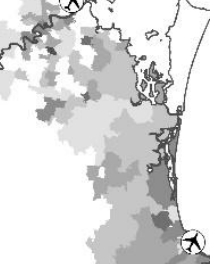

(

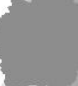

.

$\rightarrow$

International Airport Terminals

$\Delta_{N}$

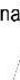

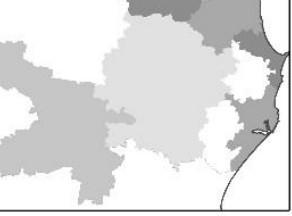

International Flights

(Japan - Tokyo \& Osằka)

,

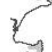

$320^{\circ}$

जon.

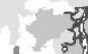

.

t)

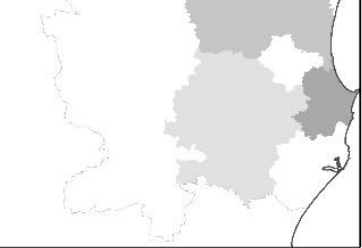

Figure 11: Map comparing the rate of trips of different destinations 


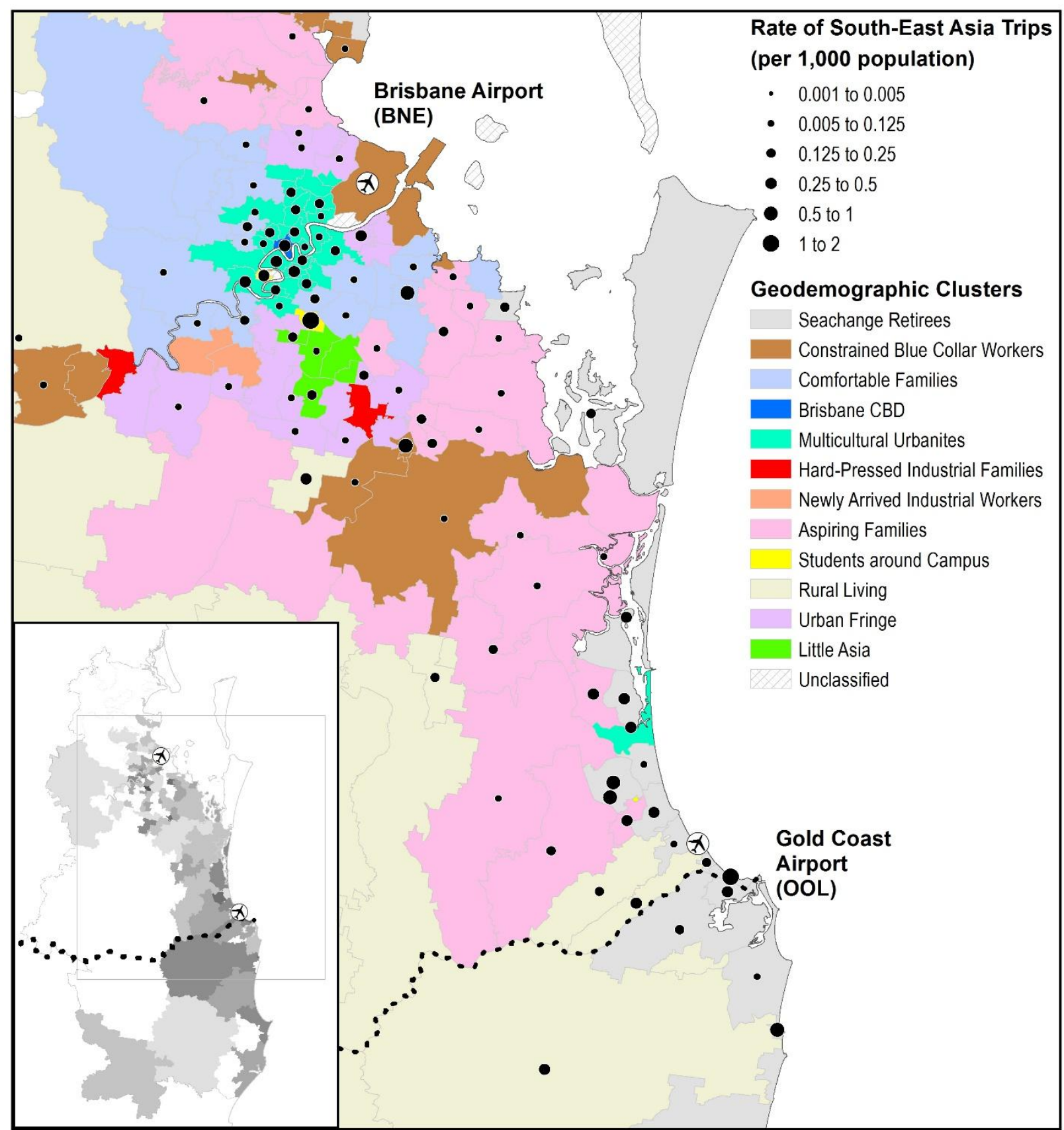

Figure 12: Overlying the rate of trips of passengers to South-East Asian destinations with geo-demographic classifications 
Appendix 1: Key variable patterns of the final geo-demographic clustering classification for the study area

\begin{tabular}{|c|c|c|c|c|c|c|c|c|c|}
\hline Group & Population & $\begin{array}{l}\text { Survey } \\
\text { (N) }\end{array}$ & $\begin{array}{l}\text { Dominant } \\
\text { Age } \\
\text { Group }\end{array}$ & Household Characteristics & $\begin{array}{l}\text { Dwelling } \\
\text { Characteristics }\end{array}$ & Socio-economic Status & Self-indicated Ethnicity & Urban Form and Transport & Example postcodes \\
\hline $\begin{array}{l}\text { Seachange } \\
\text { Retirees }\end{array}$ & 382,524 & 2,295 & $\begin{array}{l}45 \text { and } \\
\text { over }\end{array}$ & $\begin{array}{l}\text { Divorcees and widows, no children, } \\
\text { Core activities need assistance }\end{array}$ & $\begin{array}{l}\text { Semi-detached } \\
\text { owned outright }\end{array}$ & $\begin{array}{l}\text { Low education attainment and income, } \\
\text { higher part-time employment }\end{array}$ & More Australians \& British & $\begin{array}{l}\text { Mixed land use with low } \\
\text { density. Mixed mode choice }\end{array}$ & $\begin{array}{l}\text { Redcliffe (4020) } \\
\text { Labrador (4215) }\end{array}$ \\
\hline $\begin{array}{l}\text { Constrained } \\
\text { Blue Collar } \\
\text { Workers }\end{array}$ & 290,913 & 79 & Mixed & Divorcees, fewer children & $\begin{array}{l}\text { Mixed, slightly } \\
\text { more public } \\
\text { housing }\end{array}$ & $\begin{array}{l}\text { Very low education attainment, low } \\
\text { income, More blue-collar workers }\end{array}$ & $\begin{array}{l}\text { More Australians, New Zealanders, } \\
\text { British and Northwest Europeans }\end{array}$ & Low density, slightly rural uses & $\begin{array}{l}\text { Beenleigh (4207) } \\
\text { Wynnum (4178) }\end{array}$ \\
\hline $\begin{array}{l}\text { Comfortable } \\
\text { Families }\end{array}$ & 415,063 & 72 & $\begin{array}{l}0-14 \\
35-54\end{array}$ & $\begin{array}{l}\text { Mostly married and with school age } \\
\text { children }\end{array}$ & $\begin{array}{l}\text { Mostly } \\
\text { Detached } \\
\text { dwellings, } \\
\text { mostly owned or } \\
\text { in mortgage } \\
\end{array}$ & $\begin{array}{l}\text { High education attainment and } \\
\text { income, in managerial and clerical } \\
\text { occupations }\end{array}$ & $\begin{array}{l}\text { More Australians, British, and } \\
\text { Southeast Europeans }\end{array}$ & $\begin{array}{l}\text { Medium density with more } \\
\text { residential uses and car } \\
\text { ownership and usage. }\end{array}$ & $\begin{array}{l}\text { The Gap (4061) } \\
\text { Carina (4152) }\end{array}$ \\
\hline $\begin{array}{l}\text { Brisbane } \\
\text { CBD }\end{array}$ & 14334 & 42 & 25-34 & $\begin{array}{l}\text { Mostly never married and no children. } \\
\text { More tertiary students }\end{array}$ & $\begin{array}{l}\text { Predominately } \\
\text { rented flats }\end{array}$ & $\begin{array}{l}\text { Very high education attainment and } \\
\text { high incomes in managerial and } \\
\text { professional occupations }\end{array}$ & $\begin{array}{l}\text { Highly mixed but with fewer } \\
\text { Australians and British, more } \\
\text { Europeans, Asians and Americans }\end{array}$ & $\begin{array}{l}\text { Very high density and } \\
\text { commercial land use. Very } \\
\text { high active modes and high } \\
\text { public transport use. }\end{array}$ & Brisbane (4000) \\
\hline $\begin{array}{l}\text { Multicultural } \\
\text { Urbanites }\end{array}$ & 371,153 & 416 & $25-44$ & $\begin{array}{l}\text { Mostly never married and no children. } \\
\text { More tertiary students }\end{array}$ & $\begin{array}{l}\text { Mostly in rented } \\
\text { flats }\end{array}$ & $\begin{array}{l}\text { High education attainment and income } \\
\text { in managerial and clerical occupations }\end{array}$ & $\begin{array}{l}\text { Mixed but with more Southeast } \\
\text { Europeans and British }\end{array}$ & $\begin{array}{l}\text { High density and residential } \\
\text { land use. Very high public } \\
\text { transport use and high active } \\
\text { modes. }\end{array}$ & $\begin{array}{l}\text { South Brisbane (4101), } \\
\text { Fortitude Valley (4006) } \\
\text { Surfers Paradise (4217) }\end{array}$ \\
\hline $\begin{array}{l}\text { Hard- } \\
\text { Pressed } \\
\text { Industrial } \\
\text { Families }\end{array}$ & 37,348 & 5 & $0-24$ & $\begin{array}{l}\text { More divorcees and very high } \\
\text { percentage of families without children } \\
\text { and core activity needs assistance }\end{array}$ & $\begin{array}{l}\text { Very high } \\
\text { proportion of } \\
\text { public housing }\end{array}$ & $\begin{array}{l}\text { Very low education attainment and } \\
\text { income. Very high levels of low-skilled } \\
\text { occupations and very high } \\
\text { unemployment }\end{array}$ & $\begin{array}{l}\text { More Oceanians and New } \\
\text { Zealanders and Sub-Saharan } \\
\text { Africans }\end{array}$ & $\begin{array}{l}\text { Medium density with more } \\
\text { industrial land uses with lower } \\
\text { car ownership. }\end{array}$ & Logan Central (4114) \\
\hline $\begin{array}{l}\text { Newly } \\
\text { Arrived } \\
\text { Industrial } \\
\text { Workers }\end{array}$ & 31,954 & 3 & $25-44$ & Mixed - never married and divorcees & $\begin{array}{l}\text { High proportion } \\
\text { of public } \\
\text { housing }\end{array}$ & $\begin{array}{l}\text { Low education attainment and } \\
\text { income. More blue collar occupations } \\
\text { with high unemployment }\end{array}$ & $\begin{array}{l}\text { Mixed but with high levels of } \\
\text { Southeast Asians and Oceanians }\end{array}$ & $\begin{array}{l}\text { Medium density with more } \\
\text { industrial land uses with lower } \\
\text { car ownership. }\end{array}$ & $\begin{array}{l}\text { Inala (4077), } \\
\text { Darra (4076) }\end{array}$ \\
\hline $\begin{array}{l}\text { Aspiring } \\
\text { Families }\end{array}$ & 565,791 & 1,051 & $\begin{array}{l}0-14 \\
35-54\end{array}$ & $\begin{array}{l}\text { More married and with school age } \\
\text { children }\end{array}$ & $\begin{array}{l}\text { Mostly detached } \\
\text { dwellings, } \\
\text { mostly in } \\
\text { mortgage } \\
\end{array}$ & $\begin{array}{l}\text { Moderate education attainment and } \\
\text { income, in technical trades, clerical } \\
\text { and sales occupations }\end{array}$ & $\begin{array}{l}\text { More Australians \& New Zealanders, } \\
\text { British and Northwest Europeans }\end{array}$ & $\begin{array}{l}\text { Lower density residential and } \\
\text { rural land use with very high } \\
\text { levels of car usage and } \\
\text { ownership. }\end{array}$ & $\begin{array}{l}\text { Rochedale (4123), } \\
\text { Sandgate (4017) } \\
\text { Ashmore (4214) }\end{array}$ \\
\hline $\begin{array}{l}\text { Students } \\
\text { around } \\
\text { Campus }\end{array}$ & 12,229 & 21 & $15-24$ & $\begin{array}{l}\text { Predominately never married and } \\
\text { tertiary students }\end{array}$ & $\begin{array}{l}\text { Predominately } \\
\text { in rented flats }\end{array}$ & $\begin{array}{l}\text { Higher levels of education attainment, } \\
\text { very high unemployment in part-time } \\
\text { professional and sales occupations }\end{array}$ & $\begin{array}{l}\text { Mixed, with more Northeast Asians, } \\
\text { Middle Easterners, and Americans }\end{array}$ & $\begin{array}{l}\text { High-density residential land } \\
\text { uses. Low car usage and } \\
\text { ownership with higher public } \\
\text { transport and active mode use. }\end{array}$ & $\begin{array}{l}\text { St Lucia (4067), } \\
\text { Nathan (4111), } \\
\text { Bond University (4229) }\end{array}$ \\
\hline Rural Living & 230,456 & 444 & $\begin{array}{l}45 \text { and } \\
\text { over }\end{array}$ & $\begin{array}{l}\text { Mostly married and some divorcees } \\
\text { with secondary school age children. }\end{array}$ & $\begin{array}{l}\text { Predominately } \\
\text { outright owned } \\
\text { detached } \\
\text { dwellings } \\
\end{array}$ & $\begin{array}{l}\text { Lower levels of education attainment } \\
\text { with lower incomes. More managerial, } \\
\text { professional and technical trade } \\
\text { occupations. }\end{array}$ & $\begin{array}{l}\text { Mostly Australians, British, and } \\
\text { Northwest Europeans }\end{array}$ & $\begin{array}{l}\text { Very low density with mostly } \\
\text { rural uses. High car use and } \\
\text { ownership and very low public } \\
\text { transport use. }\end{array}$ & $\begin{array}{l}\text { Outer I Isswich (4306) } \\
\text { Tambourine Mountain (4272) }\end{array}$ \\
\hline $\begin{array}{l}\text { Urban } \\
\text { Fringe }\end{array}$ & 291,796 & 66 & $\begin{array}{l}0-14 \\
35-44\end{array}$ & $\begin{array}{l}\text { Mixed but with slightly more families } \\
\text { with primary school age children. }\end{array}$ & $\begin{array}{l}\text { More detached } \\
\text { dwelling under } \\
\text { mortgage. }\end{array}$ & $\begin{array}{l}\text { Medium levels of education attainment } \\
\text { and incomes and more engaged in } \\
\text { clerical or blue collar occupations. }\end{array}$ & $\begin{array}{l}\text { Mostly New Zealanders, Oceanians, } \\
\text { Southeast Europeans }\end{array}$ & $\begin{array}{l}\text { Low density with a mix of } \\
\text { industrial and residential land } \\
\text { uses. High levels of car usage } \\
\text { and ownership }\end{array}$ & $\begin{array}{l}\text { Parkinson (4115) } \\
\text { Aspley (4034) }\end{array}$ \\
\hline Little Asia & 98,618 & 26 & Mixed & $\begin{array}{l}\text { More married and with secondary } \\
\text { children or tertiary students }\end{array}$ & $\begin{array}{l}\text { More semi- } \\
\text { detached } \\
\text { dwellings either } \\
\text { owned or in } \\
\text { mortgage. }\end{array}$ & $\begin{array}{l}\text { High levels of education attainment } \\
\text { and incomes in professional or clerical } \\
\text { occupations }\end{array}$ & $\begin{array}{l}\text { Mixed but with higher levels of } \\
\text { Asians }\end{array}$ & $\begin{array}{l}\text { Medium density with mostly } \\
\text { residential uses. High level of } \\
\text { car ownership but also high } \\
\text { public transport use. }\end{array}$ & $\begin{array}{l}\text { Sunnybank (4109) } \\
\text { Calamvale (4116). }\end{array}$ \\
\hline
\end{tabular}

